\title{
PERSPEKTIF ISLAM DAN PSIKOLOGI TENTANG PEMAAFAN
}

\author{
Moh Khasan \\ Fakultas Syari'ah dan Hukum UIN Walisongo Semarang \\ Email: moh_khasan@walisongo.ac.id
}

\begin{abstract}
This study aims to explore and describe the concept of forgiveness in the perspective of Islam and psychology. The research conducted by analytical descriptive method is intended to answer the question how far the relationship between Islam and psychology about the concept of forgiveness. The research materials are taken from books, journals, and authoritative sources in Islam. The result of this research is that forgiveness is a character in the human being who strongly expresses the tendency to understand the mistakes of others, avoids revenge, always maintains good relations with others, and creates peace and safety for all. Forgiveness in the concept of Islam is dominantly influenced by religious factors (religiosity). This is because, for a Muslim, religion is the ultimate inspiration and the source of the doctrine of goodness that must be articulated in real life for the benefit and the sake of the universe.
\end{abstract}

Keywords: forgiveness, psychology, religiousity

\begin{abstract}
Abstrak
Penelitian ini bertujuan untuk mengeksplorasi dan mendeskripsikan konsep pemaafan dalam perspektif Islam dan ilmu psikologi. Penelitian yang dilakukan dengan metode deskriptif analitis ini bermaksud untuk menjawab pertanyaan sejauhmana kedekatan hubungan antara Islam dan psikologi tentang konsep pemaafan. Adapun bahan-bahan penelitian diambil dari buku, jurnal, serta sumber otoritatif dalam Islam. Hasil penelitian ini adalah bahwa Pemaafan adalah sebuah karakter dalam diri manusia yang secara kuat mengekspresikan kecenderungan untuk memahami kesalahan orang lain, menghindari balas dendam, selalu memelihara hubungan baik dengan sesama, dan menciptakan kedamaian dan keselamatan bagi semua. Pemaafan dalam konsep Islam sangat dominan dipengaruhi oleh faktor keberagamaan (religiusitas). Hal ini karena, bagi seorang Muslim, agama adalah inspirasi utama dan sumber ajaran kebaikan yang harus diartikulasikan dalam kehidupan nyata demi kemaslahatan dan kerahmatan alam semesta
\end{abstract}

Keywords: pemaafan, psikologi, religiusitas 


\section{A. Pendahuluan}

Kehidupan manusia dipenuhi dengan kejadian dan peristiwa yang tidak terduga. Sebuah peristiwa dan kejadian tertentu kadang menyenangkan dan kadang tidak menyenangkan, kadang sesuai harapan dan terkadang tidak sesuai harapan. Kondisi inilah manusia suatu ketika dituntut untuk memahami perilaku orang lain dengan jalan memaafkannya. Pemaafan dalam ilmu psikologi dikategorikan salah satu kekuatan karakter (character strength), yaitu merupakan karakter baik yang mengarahkan individu pada pencapaian keutamaan atau trait positif yang terefleksi dalam pikiran, perasaan dan tingkah laku.

Kemampuan bersabar terhadap gangguan yang ditimpakan seseorang meskipun memiliki kemampuan untuk membalasnya serta memaafkan kesalahan orang tersebut merupakan amalan yang sangat mulia. Gangguan itu bermacam-macam bentuknya. Adakalanya berupa cercaan, pukulan, perampasan hak, dan semisalnya. Memang sebuah kewajaran bila seseorang menuntut haknya dan membalas orang yang menyakitinya. Dan dibolehkan seseorang membalas kejelekan orang lain dengan yang semisalnya. Namun alangkah mulia dan baik akibatnya bila dia memaafkannya. Memaafkan kesalahan orang acapkali dianggap sebagai sikap lemah dan bentuk kehinaan, padahal justru sebaliknya. Bila orang membalas kejahatan yang dilakukan seseorang kepadanya, maka sejatinya di mata manusia tidak ada keutamannnya. Tapi di kala dia memaafkan padahal mampu untuk membalasnya, maka dia mulia di hadapan Allah dan manusia.

Pada umumnya, karakter baik pada diri seseorang tidak muncul secara tiba-tiba. Diperlukan banyak proses pembelajaran, internalisasi, dan pembiasaan. Karakter pada diri seseorang juga terbentuk oleh kontribusi faktor-faktor lain yang secara intens berinteraksi dengannya, seperti keluarga, lingkungan sosial, dan agama. Beberapa penelitian menggambarkan kuatnya hubungan antara pemaafan dengan kebergamaan (religiusitas) seseorang. Semakin tinggi pengalaman keberagamaan seseorang, maka semakin tinggi potensi pemaafan pada dirinya.

Namun demikian tidak semua penelitian menggambarkan adanya pengaruh religiusitas terhadap pemaafan. Sebuah penelitian pilot study oleh 
Tsang, McCullough dan Hyot (2005) menyatakan bahwa secara tidak langsung religiusitas memiliki potensi untuk memunculkan pemaafan pada seseorang karena pada dasarnya setiap agama mengajarkan cinta dan kasih sayang yang mendorong sikap memaafkan. Akan tetapi, hasil dari penelitian ini menunjukkan lemahnya hubungan positif antara religiusitas dan pemaafan. Selain itu dalam penelitian yang sama, Tsang, McCullough dan Hyot (2005) menyatakan bahwa religiusitas juga dapat membuat seseorang melakukan pembalasan. Hal tersebut memungkinkan religiusitas sebagai alasan seseorang untuk tidak memaafkan kesalahan orang lain. Hasil penelitian tersebut tidak sejalan dengan hasil penelitian meta analisis tentang hubungan religiusitas dan pemaafan oleh Kurniati (2011) yang menyatakan bahwa ada hubungan positif antara religiusitas dengan pemaafan akan tetapi tidak ada hubungan signifikan antara religiusitas dengan unforgiveness. ${ }^{1}$

Tulisan ini bertujuan untuk mendeskripsikan konsep pemaafan dalam perspektif Islam dan psikologi meliputi pengertian, bentuk, aspek dan dimensi, serta faktor yang mempengaruhinya. Tulisan ini juga dimaksudkan untuk memperjelas hubungan antara Islam dengan pemaafan secara konseptual.

\section{B. Pemaafan menurut Islam dan Psikologi}

1. Pengertian Pemaafan

Kata pemaafan berasal dari akar kata bahasa Arab al-'afw. Kata al'afw -yang terdiri dari tiga partikel huruf, 'ain, $f a$ ', dan satu huruf mu'tallmenurut Ibn Faris, memiliki dua makna valid, yaitu; meninggalkan (tark al-syai) dan mencari/menuntut sesuatu (thalab). Kemudian muncul banyak derivasi darinya, yang tidak memiliki perbedaan signifikan dalam hal makna. Maka, ketika dikatakan 'afw Allab 'an khalqibi, berarti tarkubu iyyahum fala yu'aqibhum (Allah membiarkan mereka, sehingga tidak menghukumnya). Al-Khalil mengatakan "setiap orang yang berhak mendapat hukuman, lalu engkau biarkan (tarakabu), maka engkau telah

\footnotetext{
${ }^{1}$ Lihat: Tri Kurniati Amrilah, Prasetyo Budi Widodo, Religiusitas dan Pemaafan dalam Konflik Organisasi pada Aktivis Islam di Kampus Universitas Diponegoro, Jurnal Empati, Oktober 2015, volume 4(4), hal. 287-292; Fuad Nashori, "Memaafkan dan Meminta Maaf”, dalam http. ://alislamiyah.uii.ac.id/2013/02/06/memaafkan-danmeminta-maaf/
} 
memaafkannya ('afaw-ta 'anbu)". Dari kata al-'afwu juga muncul kata al-'af iyah, yang berarti pembelaan atau penjagaan Allah terhadap hamba-Nya. ${ }^{2}$

Kata al-afw terulang dalam al-Quran sebanyak 34 kali, 7 kali darinya berbicara tentang pemaafan. Hal tersebut menunjukkan akhlaq saling memaafkan menjadi bagian terpenting dalam kehidupan seorang muslim. Artinya ada konsekuensi tertentu bila seseorang memaafkan atau tidak memaafkan terhadap seseorang yang pernah berbuat kesalahan kepadanya. Oleh karenanya Al-'afw (memaafkan) adalah salah satu sifat orang yang bertaqwa kepada Allah sebagaimana al-Qur'an menjelaskannya dalam QS. Ali 'Imran: 134. Ayat tersebut mendeskripsikan sikap seorang Muslim yang bertakwa akan menghadapi seseorang yang melakukan kekeliruan terhadapnya dengan tiga cara, yaitu menahan amarah, memaafkan, dan berbuat baik terhadap siapapun yang berbuat kesalahan kepadanya.

Al-'afw memiliki kedekatan makna dengan al-shafh. Dalam alMu'jam al-'Araby al-Asasy, ketika kata al-'afw dimuta'addikan ('afa-ya'fu'afwan), ia memiliki makna memaafkan (ma'f'uw 'anbn = shafaba 'anbu). Namun ketika dilazim-kan ('afa-ya'fu-'afa'an-'ufwan), ia bermakna hilang atau lenyap (zala, immaha), misalnya 'afa al-atsaru (jejak itu telah hilang). ${ }^{3}$ Baik sebagai muta'addi maupun lazim, makna kata 'afw tetap memiliki korelasi yang jelas dan berdekatan. Bukankah memaafkan seseorang berarti menganggap hilang kesalahannya? ${ }^{4}$

Kata al-shafh dalam berbagai bentuk terulang sebanyak delapan kali dalam al-Qur'an. Kata ini pada mulanya berarti lapang. Halaman pada sebuah buku dinamai shafhat karena kelapangan dan keluasannya. Dari sini, al-shafh dapat diartikan kelapangan dada. Berjabat tangan dinamai musafahat karena melakukannya menjadi perlambang kelapangan dada.

2 Abul Husein Ahmad bin Faris bin Zakariya, Mu'jm al-Maqayis fi al-Lughah, tahqiq Syihabudin Abu Amar (Beirut: Dar al-Fikr, 1994), hal. 667

3 Tim, al-Mu'jam al-'Arab al-Asasi (Alesco L'Arousse: al-Munazhamah al-'Arabiyah li alTarbiyah wa al-Tsaqafah wa al-'Ulum, 1989), hal. 851

4 Azam Bahtiar, "Al-'Afw dalam Pemikiran al-Syatibi dan Jamal al-Banna; Studi Komparatif”, dalam Jurnal Sintesis Volume 3 No. 1 Juni 2009 
Dari delapan kali bentuk al-safh yang dikemukakan, empat di antaranya didahului oleh perintah memberi maaf. Dari kata al-shafh lahirlah al-shafhat yang berarti halaman. Selembar kertas yang di dalamnya terdapat tulisan dari pensil yang salah, tentu seseorang dapat mengambil penghapus karet untuk menghapusnya. Seperti inilah ketika seseorang melakukan 'afw (memberi maaf). Seandainya kesalahan pada kertas itu ditulis dengan tinta, tentu orang tersebut akan menghapusnya dengan Tipp Ex agar tidak terlihat lagi, dan di sini orang tersebut melakukan takfir. Betapapun seseorang menghapus bekas kesalahan, pasti sedikit banyak lembaran tersebut tidak lagi sama sepenuhnya dengan lembaran baru. Malah barangkali kertas itu menjadi kusut. Di sinilah letak perbedaan antara al-shafh yang mengandung arti lapang dan lembaran baru dengan takfir. Al-shafh menuntut seseorang untuk membuka lembaran baru hingga sedikit pun hubungan tidak ternodai, tidak kusut, dan tidak seperti halaman yang telah dihapus kesalahannya.

Kata Al-shafh sebagian didahului dengan perintah memberi maaf, namun sebagian tidak. Dalam konteks al-shafh didahului dengan perintah al-'afw, perintah memaafkan tetap diperlukan, karena tidak mungkin membuka lembaran baru dengan membiarkan lembar yang telah ada kesalahannya tanpa terhapus. Itu sebabnya ayat-ayat yang memerintahkan al-shafh tetapi tidak didahului oleh perintah memberi maaf, dirangkaikan dengan jamil yang berarti indah. Selain itu, al-shafh juga dirangkaikan dengan perintah menyatakan kedamaian dan keselamatan bagi semua pihak sebagaimana dinyatakan dalam Al-Quran surat al-Hijr: 85, serta alZukhruf: 89).

Sementara itu, Ibnu Qudamah menyatakan ada tiga lafadz yang digunakan berkaitan dengan pemaafan, yaitu 1) al-'afwa berdasarkan surat al-Baqarah ayat 178; 2) Shadaq berdasarkan surat al-Maidah ayat 45; 3) alasqât. Ketiga lafadz tersebut menunjukan makna yang sama seperti lafadz yang dipergunakan dalam jual beli dan akhirnya penggunan lafadz tersebut lebih mengarah kepada maksud dari lafadz yang diucapkan untuk memaafkan. ${ }^{5}$

\footnotetext{
${ }^{5}$ Ibnu Qudamah, Al-Kafi fi fiqh Imam Abmad Ibnu Hanbal, (tahqiq Jauhar Syawisy), Juz 4, (Maktabah Islami, tt), hal. 50
} 
Pemaafan dalam bahasa Indonesia berasal dari kata dasar maaf dan imbuhan "pe-an". Menurut Tim Penyusun Kamus Besar Bahasa Indonesia (2012), maaf berarti pembebasan seseorang dari hukuman (tuntutan, denda, dan sebagainya) karena suatu kesalahan. Sementara pemaafan dapat diartikan sebagai memberi ampun karena kesalahan dan sebagainya, tidak menganggap salah lagi. ${ }^{6}$ Sedangkan dalam bahasa Inggris, kata pemaafan diartikan dari kata forgiveness. Forgiveness berasal dari kata forgive dan imbuhan ness. Oxford Advanced Learner's Dictionary of Current English, mengartikan forgive sebagai pengampunan atau menunjukkan kebaikan hati kepada seseorang (pardon or show mercy to somebody)-, tidak memelihara perasaan tidak senang kepada seseorang (no longer have hard feeling towards).

Terkait hal ini, Nashori menawarkan usulan untuk memperbaiki terjemahan kata pemaafan dalam Kamus Besar Bahasa Indonesia. Ia memberikan dua catatan terhadap terjemahan tersebut: 1) Pengertian pemaafan dalam bahasa Indonesia cenderung bersifat interpersonal atau sosial. Pengertian pemaafan dalam bahasa Arab dan bahasa Inggris cenderung bersifat intrapersonal dengan sasaran interpersonal. Simpulan yang dapat dibuat, pemaafan adalah menghapuskan luka hati serta dampaknya seperti tuntutan hukum, dan sebagainya; 2) Pengertian pemaafan dalam Kamus Besar Bahasa Indonesia tampaknya perlu diperbaiki karena membatasi pemaafan hanya pada "pembebasan dari hukuman". Pemaafan semestinya diberi pengertian yang lebih luas, termasuk kebaikan hati kepada pelaku pelanggaran. ${ }^{7}$

Kata pemaafan juga memiliki kedekatan dengan bidang ilmu psikologi. Berbeda dengan ahli bahasa, ahli psikologi memberi pengertian pemaafan relatif lebih luas. Oleh ahli psikologi, pemaafan terhadap seseorang dibedakan dari excusing (membebaskan) yang tidak mengakui ketidakadilan, reconciling (berdamai) yang melibatkan saling percaya kedua

\footnotetext{
6 Kamus Besar Bahasa Indonesia versi Online dalam http://kbbi.web.id/maaf, diakses tanggal 25 Juli 2017 pukul 20.00.

7 Lihat: Fuad Nashori, "Meningkatkan Kualitas Hidup dengan Pemaafan”, dalam Jurnal Unisia, Vol. 32 No. 75, Juli 2011, hal. 214-215
} 
belah pihak, dan forgetting (melupakan) yang tidak benar-benar membebaskan. ${ }^{8}$

Robert D. Enright, salah seorang ahli psikologi menyatakan bahwa pemaafan adalah kesediaan seseorang untuk meninggalkan kemarahan, penilaian negatif, dan perilaku acuh-tidak-acuh terhadap orang lain yang telah menyakitinya secara tidak adil. ${ }^{9}$ Menghapus dan melupakan perilaku jahat orang lain menjadi salah satu elemen penting pemaafan. Sebagaimana digambarkan oleh Nashori, bahwa pemaafan adalah menghapus luka atau bekas-bekas luka dalam hati. Boleh jadi ingatan kejadian yang memilukan di masa lalu masih ada, tetapi persepsi kejadian yang menyakitkan hati telah terhapuskan. ${ }^{10}$

Adapun Thompson mendefinisikan pemaafan sebagai upaya untuk menempatkan peristiwa pelanggaran yang dirasakan sedemikian hingga respon seseorang terhadap pelaku, peristiwa, dan akibat dari peristiwa yang dialami diubah dari negatif menjadi netral atau positif. ${ }^{11}$ Senada dengan ini, Walrond-Skinner menyimpulkan dengan pertimbangan teoritis bahwa pemaafan bertindak sebagai sebuah reframe karena ia memungkinkan seseorang untuk melihat dan mengalami (memperlakukan) kejadian masa lalu yang menyakitkan dengan cara pandang yang berbeda. Pemaafan juga merupakan agen pemberdayaan sementara karena ia merubah keseimbangan kekuasaan dalam sebuah hubungan. Biasanya, kekuasaan terletak pada pelanggar (pelaku). Selain itu, pemaafan bertindak secara paradoks untuk melepaskan (meredakan) konflik dua belah pihak karena ia menghilangkan banyak kebingungan yang muncul dengan perasaan ambivalensi seputar pelanggaran itu.

\footnotetext{
8 T.W. Baskin \& R.D. Enright, "Intervention Studies on Forgiveness: A Meta-Analysis", dalam Journal of Counseling \& Development, Vol. 82 (Winter), 2004, hal. 77-82

9 R.D. Enright, Anthony Dio Martin, Emotional Quality Management: Refleksi, Revisi dan Revitalisasi Hidup Melalui Kekuatan Emosi (Jakarta: Penerbit Arga. 2003), hal. 20.

${ }^{10}$ Baca: Fuad Nashori, M.Si, Psi., Psikologi Sosial Islami, (Bandung: PT. Refika Aditama, 2008).

${ }^{11}$ L.Y. Thompson, Snyder, C.R., Hoffman, L., Michael, S.T., Rasmussen, H.N., Billings, L.S., Heinze, L., Neufeld, J.E., Shorey, H.S., Roberts, J.C., \& Robert, D.E., Dispositional Fogiveness of Self, Other, and Situation, Journal of Social and Personality Psychology, 73 (2)., 2005, hal. 313-359.
} 
McCullough, Worthington, \& Rachal mendefinisikan pemafaan sebagai reduksi perubahan yang bersifat motivasional untuk balas dendam dan motivasi untuk menghindar orang yang telah menyakiti, yang cenderung mencegah respon yang destruktif dalam relasi sosial dan mendorong seseorang untuk menunjukan perilaku yang konstruktif terhadap orang yang telah menyakitinya. ${ }^{12}$ Pada kesempatan lain, McCullough mengatakan pemaafan adalah serangkaian perubahan motivasi/perilaku dengan jalan menurunkan motivasi untuk membalas dendam, menjauhkan diri atau menghindar dari perilaku kekerasan dan meningkatkan motivasi ataupun keinginan untuk berdamai dengan pelaku. $^{13}$

Dari beberapa definisi di atas disimpulkan bahwa pengertian pemaafan meliputi beberapa unsur pokok, yaitu: menghapuskan dan melupakan semua perasaan sakit dan ketidakadilan yang ditimbulkan akibat perbuatan orang lain karena adanya motivasi untuk membangun hubungan yang lebih baik. Hal ini sebagimana Gustafson mendiskripsikan pemaafan ke dalam lima poin yaitu adanya; deciding, punishing, perceiving an injustice, taking action, experiecing emotional relief. Kelima point tersebut diambil dari pengertian yang ia buat yaitu: "forgiveness means deciding not to punish a perceived injustice, taking action on thet decision, and experiencing the emotional relief that follows. ${ }^{14}$

\section{Pemaafan dalam Tradisi Islam}

Kata al'afw terulang dalam Al-Quran sebanyak 34 kali. Menurut Quraish Shihab, kata ini pada mulanya berarti berlebihan (QS [2]: 219). Maksudnya, yang berlebih seharusnya diberikan agar keluar. Keduanya menjadikan sesuatu yang tadinya berada di dalam (dimiliki) menjadi tidak di dalam dan tidak dimiliki lagi. Akhirnya kata al-'afw

\footnotetext{
12 M.E. McCullough, Jr. Worthington, \& K.C. Rachal, Interpersonal Forgiving in Close Relationships, Journal of Personality and Social Psychology, 1997, hal. 321

${ }_{13}$ McCullough, Fincham \& Tsang, Forgiveness, Forbearence, and Time: the Temporal Unfolding of Transgression-Related Interpersonal Motivations, Journal of Personality and Social Psychology, vol. 84, 2003, hal. 540

14 Mona Gustafson-Affinito, When to Forgive: A Healing Guide, (CA: New Harbinger Publication, 1999), hal. 11
} 
berkembang maknanya menjadi keterhapusan. Memaafkan, berarti menghapus luka atau bekas-bekas luka yang ada di dalam hati. ${ }^{15}$

Membandingkan ayat-ayat yang berbicara tentang tobat dan maaf, ditemukan bahwa kebanyakan ayat tersebut didahului oleh usaha manusia untuk bertobat. Sebaliknya, tujuh ayat yang menggunakan kata 'afa, dan berbicara tentang pemaafan semuanya dikemukakan tanpa adanya usaha terlebih dahulu dari orang yang bersalah. ${ }^{16}$

Selanjutnya, beberapa ayat dalam al-Qur'an ternyata tidak ditemukan satu ayat pun yang menganjurkan agar meminta maaf, tetapi yang ada adalah perintah untuk memberi maaf, seperti surat Ali-Imran: 152 dan 155; surat al-Maidah: 95 dan 101. Demikian juga yang dikesankan oleh sebuah ayat yang menganjurkan untuk tidak menanti permohonan maaf dari orang yang bersalah, melainkan hendaknya memberi maaf sebelum diminta. Mereka yang enggan memberi maaf pada hakikatnya enggan memperoleh pengampunan dan Allah (al-Nur: 22). ${ }^{17}$

Sejarah telah mengilustrasikan dengan jelas bahwa pemaafan menjadi nilai dan prinsip dasar yang selalu dijunjung tinggi dalam Islam. Rasulullah saw seringkali mengingatkan dan mengajarkan untuk mencari

15 M. Quraish Shihab, Wawasan Al-Qur'an, Tafsir Tematik atas Pelbagai Persoalan Umat (Bandung: Mizan, 2007), hal. 326-327

${ }_{16}$ Ayat-ayat tersebut dapat ditemukan dalam surat al-Baqarah: 187; surat al-Tawbah: 43, dan surat al-Syura: 40.

17 Namun, dalam hal ini sebuah hadits menyatakan perintah untuk berusaha agar dihalalkan dosa-dosa kita kepada saudara kita, yang berarti kita diminta untuk meminta maaf atau dimaafkan. Hal ini sebagaimana diungkapkan sebuah hadis Nabi saw. Abu Hurairah berkata, telah bersabda Rasulullah saw, "Barangsiapa pernab melakukan kedzaliman terbadap saudaranya, baik menyangkut kehormatannya atau sesuatu yang lain, maka hendaklah ia minta dibalalkan darinya hari ini, sebelum dinar dan dirbam tidak berguna lagi (bari kiamat). (Kelak) jika dia memiliki amal shaleh, akan diambil darinya senkuran kedralimannya. Dan jika dia tidak mempunyai kebaikan (lagi), akan diambil dari keburukan saudara (yang dizalimi) kemudian dibenankan kepadanya. (HR al-Bukhari). Karenanya, pilihan yang lebih proaktif, yaitu meminta maaf, menjadi pilihan yang lebih menjamin kepastian dihapuskannya dosa-dosa. Meminta maaf jelas merupakan salah satu bentuk kerendahhatian (tawadbu) pribadi dan tentu juga merupakan salah satu bentuk keberanian manusia. Baca: M. Quraish Shihab, Wawasan al-Qur'an, Tafsir Tematik atas Pelbagai Persoalan Umat, hal. 328-329.; Fuad Nashori, "Memaafkan dan Meminta Maaf', dalam bttp. ://alislamiyah.uii.ac.id/2013/02/06/memaafkan-dan-meminta-maaf/ 
anugerah yang besar dari Allah, salah satunya sabar dan memaafkan orang lain, meskipun mereka adalah musuh. Beberapa peristiwa besar dalam sejarah Islam masa nabi telah menggambarkan dengan jelas prinsip-prinsip pemaafan dalam Islam, yaitu: Piagam Madinah, Haji Wada', peristiwa Tha'if, dan Fathu Makkah. Peristiwa Hijrah yang pada akhirnya mengisnpirasi perumusan Piagam Madinah (622 M) mencerminkan sebuah gentlment agreement dan terciptanya ummah, telah menjadi sebuah model kesepakatan yang melampaui batas-batas agama, suku, dan kelompok.

Demikian juga pada peristiwa Haji Wada', nabi semakin memperjelas dan memperkuat prinsip-prinsip fundamental pada persamaan, rekonsiliasi, dan pemaafan antara semua ummat melalui khutbah wada'nya. Sementara pada peristiwa di Thaif dan Fatbu Makeah, telah dibuktikan sebuah ketulusan hati nabi untuk tidak membalas apa yang telah mereka (penduduk Makkah dan Thaif) lakukan, melainkan motivasi yang tinggi untuk memaafkan mereka. ${ }^{18}$ Demonstrasi tingginya moral dalam Islam juga pernah ditunjukkan oleh Abu Bakar ketika memaafkan Mistah, salah seorang yang telah memfitnah Siti 'Aisyah. Beliau memafkannya meskipun Mistah bisa diancam dengan hukuman yang berat. ${ }^{19}$

Fenomena Piagam Madinah juga telah menginspirasi Fethullah Gulen, seorang yang dikategorikan tradisionalis karena kedekatannya dengan pendekatan sufistik, dan banyak dipengaruhi oleh tradisi Sufi Mevlevi dan pemikiran Said Nursi. Dalam Risale-i Nur ia memberikan perhatiannya yang besar terhadap dunia pendidikan dan dialog untuk mendukung isu-isu tentang toleransi, pemaafan, dan perdamaian. Didasari oleh analisisnya tentang Piagam Madinah dan khutbah wada', ia menyimpulkan bahwa toleransi sebenarnya merupakan sebuah kewajiban, bukan sekedar nilai. Pemaafan sangat bernilai dan terkait dengan toleransi. Ia mengatakan: "Kita harus memiliki sikap toleransi semacam itu sehingga dapat menutup mata terhadap kesalahan orang lain,

18 Abi Ja'far Muhammad bin Jarir al-Thabari, Jami' al-Bayan 'an Ta'wil al-Qur'an, (Kairo: Maktabah ibn Taimiyyah, 1997), hal. 162

${ }^{19}$ Safi al-Ramadhan Mubarakfuri, Tafsir Ibn Katsir, Juz 3, (Riyadh: Darussalam, 2003), hal. 286-287 
menghargai pendapat yang berbeda, dan memaafkan segala sesuatu yang mesti dimaafkan"20

Dalam perspektif hukum Islam, pemaafan dikenal sebagai salah satu isu dalam hukum pidana Islam (jinayah), yaitu dalam jarimah qisasdiyat. Qisas merupakan tradisi yang berasal dari Arab pra-Islam. AlQur'an merespons praktik qisas dengan menginkulturasikan nilai baru, yaitu: keadilan, kesetaraan, moralitas, dan pertanggungjawaban individu. Paradigma qisas dalam al-Qur'an menekankan pada prinsip rehabilitatif, yaitu mereformasi moralitas masyarakat, khususnya pelaku tindak pembunuhan. Hal ini dapat dilihat dengan adanya alternatif hukuman yang ditawarkan al-Qur'an, yaitu membayar diyat, memberi maaf, dan menyelesaikannya dengan perdamaian. Alternatif hukuman ini bertujuan untuk menyelesaikan konflik dengan mengedepankan toleransi dan menghilangkan rasa dendam. Hukuman qisas bukan semata-mata untuk melakukan social control dengan membalas kejahatan, tetapi untuk social engineering yaitu menjaga kelangsungan kehidupan manusia. ${ }^{21}$

Ayat 179 surat al-Baqarah mejelaskan bahwa dasar filosofis diberlakukannya hukum qisas bukanlah bersifat retributif atau hukuman pembalasan atas perbuatan kriminal yang telah dilakukan. Hal ini mempunyai konsekwensi bahwa tidak setiap orang yang membunuh harus dihukum qisas, karena yang demikian itu menyalahi tujuan dasarnya. Inilah sebabnya setiap ada kasus pembunuhan yang dilaporkan kepada nabi tidak langsung dikenai hukuman qisas. Bahkan hal yang pertama kali disarankan Nabi adalah menyuruh wali korban untuk memaafkannya. ${ }^{22}$ Oleh menurut Fikri Ahmad 'Akkaz, dalam Falsafat al'Uqubah fi al'Syari'at wa al-Qanun, ada pernyataan yang terkenal diantara fuqaha: al-'Afw afdhal min al-sulh, wa al-sulh afdhal min al-qisas (memaafkan itu lebih utama daripada berdamai; dan berdamai itu lebih utama daripada

20 Russell Powell, "Forgiveness in Islamic Ethics and Jurisprudence", dalam Berkeley Jurnal of Middle Eastern and Islamic Law, Vol. 4:1, 2012, hal. 31-32

21 Ali Sodiqin, Hukum Qiyas, Dari Tradisi Arab Menuju Hukum Islam, (Yogyakarta: Tiara Wacana, 2010), hal. 192-193

22 Abi Abdurrahman Ahmad ibn Syu'aib ibn 'Ali al-Khurasani al-Nasa'i, Sunan al-Nasa', (Beirut: Dar al-Kutub al-Ilmiyyah, 2002), hal. 760; Abi Abdillah Muhammad ibn Yazid alQazwini, Sunan Ibn Majah, Juz III, (Beirut: Dar al-Ma'rifah, 2000), hal. 299 
qisas). Semestinya orang mukmin itu menjadi pemaaf sebagaimana firman-Nya: faman 'afa wa ashlaha fa ajrubu 'ala Allab. ${ }^{23}$

Pemaafan merupakan salah satu asas penerapan sanksi qisas dalam Islam. Bahwa dalam jarimah pembunuhan, seorang pembunuh telah memutuskan hubungan dengan seorang atau sebuah kaum. Dengan dilakukan qisas, maka putusnya hubungan ini tetap berlanjut. Oleh karena itu obat dari situasi ini hanya satu yaitu pemaafan. Dengan pemaafan, hubungan antara keduanya menjadi terpelihara, kasih sayangnya menjadi terbangun kembali (diperbarui), keburukan antara keduanya menjadi hilang. Atas dasar inilah Tuhan sangat menyukai pemaafan terhadap pelaku kejahatan, sebagaimana diperintahkan dalam al-Qur'an (QS. 2: 178). ${ }^{24}$

\section{Aspek, Dimensi, dan Bentuk Pemaafan}

1. Aspek, Dimensi dan Bentuk

Pemaafan merupakan salah satu karakter manusia yang menunjukkan watak mereka (temperance). Temperance adalah karakter yang mengarah kepada kekuatan yang melindungi dari sesuatu yang berlebihan. Menurut Park, Peterson, \& Seligman, pemaafan juga merupakan salah satu refleksi kekuatan karakter (character strength), yaitu merupakan karakter baik yang mengarahkan individu pada pencapaian keutamaan atau trait positif yang terefleksi dalam pikiran, perasaan dan tingkah laku. ${ }^{25}$ Orang

${ }^{23}$ Dr. Fikri Ahmad al-'Akkaz, Falsafat al-'Uqubah fi al-Syari'ab wa al-Qanun, (tp., 1982), hal. 179

${ }^{24}$ Dr. Fikri Ahmad al-'Akkaz, Falsafat al-Uqubah fi al-Syari'ah wa al-Qanun, hal. 179. Keberadaan ketentuan tentang pemaafan dalam hukum positif di Indonesia terasa semakin dibutuhkan mengingat semakin banyak kasus hukum pidana yang semestinya tidak perlu dihukum (tapi cukup dengan dimaafkan). Namun karena tidak ada asas legalitas yang dapat menjadi dasar akhirnya kasus-kasus tersebut terpaksa dihukum. Seakan-akan dengan menjatuhkan hukuman itulah satu-satunya cara keadilan hukum dapat menjadi tegak. Kasus "pencurian biji kakao" nenek Minah di Banyumas (2009), "biji randu" Manisih dkk di Batang (2009), "pencurian sandal jepit" di Palu Sulawesi Tengah (2012), "pencurian kayu jati" nenek Asyani di Situbondo (2014), dan lain-lain adalah sebagian potret kesenjangan hukum dan keadilan tersebut. Terkait keadilan hukum dan Asas Legalitas, baca: Moh Khasan, "Prinsip-Prinsip Keadilan Hukum dalam Asas Legalitas Hukum Pidana Islam” dalam Jurnal Rechts Vinding, Vol. 6, Nomor 1, April 2017, hal. 21-36

25 Baca: C. Peterson, N. Park, M.E.P. Seligman, "Greater Strength of Character and Recovery from Illness", Journal of Positive Psychology, 2006. 
yang memiliki karakter pemaaf, ditandai dengan adanya penguatan beberapa aspek dalam dirinya, meliputi kemauan untuk memaafkan orang lain yang berbuat salah, menerima kekurangan orang lain, memberikan kesempatan kepada orang lain, dan tidak mendendam kepada orang lain yang telah berbuat salah kepadanya.

Sedangkan berdasarkan pengertian McCullough sebelumnya, dapat disimpulkan bahwa pemaafan dapat ditandai dengan keberadaan aspek-aspek, meliputi: perubahan serangkaian perilaku dengan jalan menurunkan motivasi untuk membalas dendam kepada pelaku kejahatan, menjauhkan diri atau menghindar dari perilaku kekerasan, dan meningkatkan motivasi ataupun keinginan untuk berdamai dan berbuat baik dengan pelaku. ${ }^{26}$

Adapun dalam perspektif Islam, aspek-aspek pemaafan dapat mencakup banyak hal, seperti: menahan amarah, memaafkan kesalahan, berbuat baik terhadap siapapun yang berbuat kesalahan kepadanya, lapang dada, keluasan hati, menghapus kesalahan, melupakan masa lalu yang menyakitkan hati, takfir (menutup kesalahan orang lain), membuka lembaran baru, memperbaiki hubungan menjadi indah (harmonis), mewujudkan kedamaian dan keselamatan bagi semua pihak, mendoakan orang yang berbuat jahat, bermusyawarah dengan orang-orang yang pernah menyakiti (berbuat salah), dan menyerahkan urusan kepada Allah (tawakkal). Aspek-aspek pemaafan ini tersebar dalam beberapa ayat alQur'an dan dapat diklasifikasikan sebagai berikut:

Tabel 1: Penyebaran Aspek Pemaafan dalam Al-Qur'an ${ }^{27}$

\begin{tabular}{lrl}
\hline NO & AL-QUR'AN & \multicolumn{1}{c}{ ASPEK PEMAAFAN } \\
\hline \multirow{2}{*}{1} & Ali Imran: 134 & $\begin{array}{l}\text { Menahan amarah, memaafkan } \\
\text { kesalahan, dan berbuat baik terhadap } \\
\text { siapapun yang berbuat kesalahan }\end{array}$ \\
& &
\end{tabular}

\footnotetext{
${ }^{26}$ McCullough, Fincham \& Tsang, Forgiveness, Forbearence, and Time, hal. 540.

27 Al-Qur'an dan Terjemahnya, Jakarta: Yayasan Penyelenggara dan Penterjemah/Pentafsir Al-Qur'an, 1990)
} 


\begin{tabular}{|c|c|c|}
\hline 2 & Al-Nur: 22 & Berlapang dada dan keluasan hati \\
\hline 3 & Al-Syura: 40 & $\begin{array}{l}\text { Menghapus kesalahan orang lain, } \\
\text { melupakan masa lalu yang menyakitkan } \\
\text { hati, dan takfir (menutup kesalahan } \\
\text { orang lain) }\end{array}$ \\
\hline 4 & Al-Hijr: 85 & $\begin{array}{l}\text { Membuka lembaran baru, dan } \\
\text { memperbaiki hubungan menjadi indah } \\
\text { (harmonis) }\end{array}$ \\
\hline 5 & Al-Zukhruf: 89 & $\begin{array}{l}\text { Mewujudkan kedamaian dan } \\
\text { keselamatan bagi semua pihak }\end{array}$ \\
\hline 6 & Ali Imran: 159 & $\begin{array}{l}\text { Mendoakan orang yang berbuat jahat, } \\
\text { bermusyawarah dengan mereka, dan } \\
\text { menyerahkan urusan kepada Allah } \\
\text { (tawakkal) }\end{array}$ \\
\hline 7 & Al-Baqarah: 219 & Menjadi pemaaf \\
\hline 8 & Al-Baqarah: 178 & $\begin{array}{l}\text { Bagi yang dimaafkan, mengikuti } \\
\text { keinginan/permintaan korban } \\
\text { (bekerjasama, rekonsiliasi) dan } \\
\text { memberikan ganti rugi (diyat) dengan } \\
\text { baik }\end{array}$ \\
\hline
\end{tabular}

Islam menganjurkan untuk memberikan maaf secara sungguhsungguh dan tidak dilakukan dengan syarat-syarat tertentu, bahkan tanpa diminta. Lebih dari itu juga dianjurkan untuk melebihkan pemberian maaf itu dengan mendoakan orang yang berbuat salah sebagaimana dicontohkan oleh Nabi. Dengan kata lain, pemaafan tidak hanya di bibir, tapi sampai di hati. Islam memberikan resep agar pemaafan tuntas, yakni memohonkan ampunan (mendoakan) bagi mereka serta bermusyawarah. Hal ini sebagaimana diperintahkan dalam al-Qur'an surat Ali-Imran $159 .{ }^{28}$

${ }^{28}$ Ayat tersebut diterjemahkan sebagai berikut: 
Selain itu Islam juga mengajarkan untuk tetap menjaga keselamatan dan kedamaian bagi semua pihak. Artinya, dengan dilakukan pemaafan, maka akan terwujudlah perdamaian dan keselamatan (al-Zukhruf: 89). Dua nilai penting inilah yang menjadi pembeda antara konsep Islam dan ilmu psikologi.

Nashori menegaskan bahwa termasuk pengertian memohonkan ampun bagi mereka adalah mendoakan kebaikan bagi mereka, mengusahakan kebaikan bagi mereka, dan sebagainya. Melalui ayat tersebut, Allah juga memerintahkan manusia agar luka yang pernah ada jangan sampai semakin menganga dikarenakan munculnya sebab kemarahan, yaitu dengan bermusyawarah. Oleh karena itu, bermusyawarahlah sebagaimana disampaikan ayat tersebut agar dua orang atau lebih yang pernah konflik hendaknya membuat kesepakatankesepakatan sebelum bekerjasama lagi agar peristiwa yang menyakitkan hati tidak lagi terulang. ${ }^{29}$

Ahli ilmu psikologi menyatakan bahwa pemaafan dapat terdapat dalam dua dimensi, yaitu intrapsikis dan interpersonal. Dimensi intrapsikis melibatkan keadaan dan proses yang terjadi di dalam diri orang yang disakiti secara emosional maupun pikiran dan perilaku yang menyertainya. Sedangkan dimensi interpersonal lebih melihat bahwa memaafkan orang lain merupakan tindakan sosial antara sesama manusia. Maksudnya disini adalah langkah menuju mengembalikan hubungan kepada kondisi semula sebelum peristiwa yang menyakitkan terjadi. ${ }^{30}$

"Maka disebabkan rahmat dari Allâh-lab kamu berlaku lemah lembut terbadap mereka. Sekiranya kamu bersikap keras lagi berbati kasar, tentulah mereka menjaubkan diri dari sekelilingmu. karena itu ma'afkanlah mereka, mohonkanlah ampun bagi mereka, dan bermusyawaratlah dengan mereka dalam urusan itu. Kemudian apabila kamu telah membulatkan tekad, maka bertawakkallah kepada Allâh. Sesunggubnya Allâh menyukai orang-orang yang bertawakkal kepada-Nya. (QS Ali 'Imron [3]: 159)

29 Fuad Nashori, "Memaafkan dan Meminta Maaf", dalam bttp. ://alislamiyah.uii.ac.id/2013/02/06/memaafkan-dan-meminta-maaf/; Lihat juga: Fuad Nashori, Pemaafan pada Etnis Jawa Ditinjau dari Faktor Demografi, dalam Jurnal Psikologika Vol 18 No. 2 Tahun 2013.

${ }^{30}$ R. F. Baumeister, , J. J. Exline, and K. L. Sommer, The victim role, grudge theory, and two dimensions of forgiveness, dalam E. L. Worthington, Jr. (eds.), Dimensions of forgiveness: Psychological Research and Theological Speculations (Philadelphia: The Templeton Foundation Press, 1998). 
Dimensi intrapsikis dan dimensi interpersonal ini saling berinteraksi dan akan menghasilkan beberapa kombinasi pemaafan, sebagaimana dapat dilihat sebagai berikut:

Tabel 2: Dua Dimensi Pemaafan dan Kombinasi yang Dapat Terjadi

\begin{tabular}{|c|c|c|}
\hline Dimension & $\begin{array}{c}\text { Type of } \\
\text { Forgiveness }\end{array}$ & \\
\hline Interpersonal Act + & Hollow & Kombinasi ini terjadi saat \\
\hline \multirow{13}{*}{$\begin{array}{l}\text { No } \\
\text { State }\end{array}$} & Forgiveness & orang yang disakiti dapat \\
\hline & & mengekspresikan pemaafan \\
\hline & & secara konkret melalui \\
\hline & & perilaku, namun orang yang \\
\hline & & belum dapat \\
\hline & & memahami dan menghayati \\
\hline & & adanya pemaafan di dalam \\
\hline & & dirinya. Orang yang disakiti \\
\hline & & masih menyimpan rasa \\
\hline & & dendam, kebencian meskipun \\
\hline & & ia telah mengatakan kepada \\
\hline & & pelaku "saya memaafkan \\
\hline & & kamu” \\
\hline \multirow{7}{*}{\multicolumn{2}{|c|}{$\begin{array}{l}\text { Intrapsychic State }+ \text { Silent Forgiveness } \\
\text { No Interpersonal }\end{array}$}} & Merupakan kebalikan dari \\
\hline & & bollow \\
\hline & & forgiveness. Kombinasi ini, \\
\hline & & intrapsikis \\
\hline & & namun tidak \\
\hline & & ditampilkan \\
\hline & & perbuatan dalam hubungan \\
\hline
\end{tabular}




\begin{tabular}{|c|c|}
\hline & $\begin{array}{l}\text { interpersonal, no interpersonal } \\
\text { forgiveness. Orang yang disakiti }\end{array}$ \\
\hline & tidak lagi menyimpan \\
\hline & perasaan marah, dendam, \\
\hline & benci kepada pelaku namun \\
\hline & tidak mengekspresikan. \\
\hline & Orang yang disakiti \\
\hline & membiarkan pelaku terus \\
\hline & merasa bersalah dan terus \\
\hline & bertindak seolah-olah pelaku \\
\hline & tetap bersalah. \\
\hline Intrapsychic State + Total Forgiveness & Intrapsikis dan interpersonal \\
\hline Interpersonal Act & pemaafan terjadi. Orang yang \\
\hline & menghilangkan \\
\hline & perasaan negatif seperti \\
\hline & kekecewaan, benci, atau \\
\hline & marah terhadap pelaku \\
\hline & tentang peristiwa yang \\
\hline & terjadi, dan pelaku \\
\hline & dibebaskan secara lebih lanjut \\
\hline & dari perasaan bersalah dan \\
\hline & kewajibannya. Kemudian \\
\hline & hubungan antara orang yang \\
\hline & disakiti dengan pelaku \\
\hline & kembali menjadi baik seperti \\
\hline & sebelum peristiwa \\
\hline & menyakiti terjadi. \\
\hline No Intrapsychic No Forgiveness & Intrapsikis dan interpersonal \\
\hline
\end{tabular}




\begin{tabular}{ll}
\hline State + No & pemaafan tidak terjadi pada \\
Interpersonal Act & orang yang disakiti. \\
\hline
\end{tabular}

Sumber: Baumester, Exline \& Sommer, ${ }^{31}$

Selanjutnya terkait dengan tipe pemaafan, Walrond-Skinner mengembangkan enam tipe pemaafan, yaitu: Pertama, prematur atau instantaneous forgiveness. Tipe pemaafan ini dianggap dangkal karena pemaafan ditawarkan sebelum isu-isu tentang pelanggaran itu telah ditetapkan. Kedua, arrested forgiveness, yaitu manakala salah seorang atau kedua pihak menyangkal pentingnya pemaafan. Ketiga, conditional forgiveness, yaitu ketika pemaafan ditawarkan dalam pertukaran terhadap sesuatu yang lain. Keempat, pseudo forgiveness, yaitu tipe pemaafan yang ditawarkan atau diterima setelah kedua pihak meyakini bahwa pemaafan telah terjadi terlepas dari kenyataan bahwa mereka telah menyangkal pelanggaran itu dan konsekwensinya. Kelima, collusive forgiveness, yaitu pemaafan yang ditawarkan dengan maksud untuk menghindari oposisi atau konflik meskipun pelanggaran terjadi lagi. Keenam, repetitious forgiveness, yaitu manakala upaya untuk memaafkan tidak berhasil karena tidak memungkinkan untuk diadakan pemaafan murni, dan tidak adanya kebebasan para pihak dari konsekuensi-konsekuensinya. ${ }^{32}$

Dalam Islam, ketentuan tentang pemaafan secara khusus diulas dalam fikib jinayah (ketentuan hukum Islam yang mengatur tentang pidana). Secara definitif disebutkan bahwa ketika terjadi peristiwa pembunuhan atau pelukaan secara sengaja, maka ada tiga pilihan solusi hukum, yaitu qisas (balasan setimpal dengan kejahatannya), diyat (pembayaran uang darah kepada korban/walinya karena pemaafan tidak absolut), dan pembebasan dari hukuman karena pemaafan absolut dari

\footnotetext{
31 Baca: R. F. Baumeister, , J. J. Exline, and K. L. Sommer, The victim role, grudge theory, and two dimensions of forgiveness, dalam E. L. Worthington, Jr. (eds.), Dimensions of forgiveness.

32 Baca: Sue Walrond Skinner, "The function and role of forgiveness in working with couples and families: Clearing the ground",Journal of Family Therapy, 1998.
} 
korban/walinya. ${ }^{33}$ Berdasarkan ketentuan tersebut, maka tipologi pemaafan dapat diklasifikasikan menjadi dua, yaitu pemaafan non absolut dan pemaafan absolut. Pemaafan non absolut adalah tipe pemaafan yang bersyarat, yakni dengan meminta kompensasi lain berupa pembayaran restitusi (diyat). Sedangkan pemaafan absolut adalah tipe pemaafan yang sempurna dan tidak bersyarat. Korban sama sekali tidak menuntut kompensasi atas kejahatan yang dilakukan oleh pelaku.

\section{Skala Pemaafan (forgiveness scale)}

Skala pemaafan (forgiveness scale) terdiri dari tiga subskala: perasaan (feeling), pemikiran (thought), dan behaviors (perilaku). Subskala ini memungkinkan peneliti untuk mengukur tiga komponen tertentu dari pemaafan. Subskala feeling, diukur dengan bentuk negative feelings: kebencian (hatred), amukan (rage), and kemarahan (anger) dan positive feelings: peduli (care), belas kasihan (compassionate), dan penerimaan (acceptance). Secara perilaku (behaviorally), pemaafan diukur dalam bentuk bertumpu kepada Tuhan (focuse toward God), perdamaian (conciliation), dan tidak menaruh dendam (not holding a grudge). Secara kognitif (thought), pemaafan diukur dengan pertanyaan-pertanyaan yang memfokuskan pada kebebasan dari godaan (obsession), penguatan (affirmation), balas dendam (revenge), dan penipuan (victimization). ${ }^{34}$

Adapun skala pemaafan dalam Islam setidaknya dapat diukur melalui indikator-indikator sebagai berikut;

\footnotetext{
33 Ada perbedaan pendapat diantara imam madzhab terkait ketentuan ini. Selengkapnya baca: Abdul Qadir Audah, al-Tasyri' al-Jina'i al-Islami, (Beirut: Muassasah al-Risalah, 1994); Ahmad D. Hanafi, Asas-Asas Hukum Pidana Islam, (Jakarta: Bulan Bintang, 1993); Ahsin Sakho Muhammad, et.al (eds), Ensiklopedi Hukum Pidana Islam, Jakarta: PT. Kharisma Ilmu, 2007); M. Cherif Bassiouni, (ed.), The Islamic Criminal Justice System, (New York: Oceana Publications, 1982); al-Mawardi, al-Ahkam al-Sulthaniyah (Mesir: Babi al-Halabi, 1973)

34 S.B. Wade, Gorsuch, R., \& Rosik, C.H., "The development of a scale to measure forgiveness", Journal of Psychology and Christianity, 1990, hal. 40-52
} 
Tabel 3: Skala Pemaafan dalam Islam (disarikan dari ayat-ayat al-Qur'an) $)^{35}$

\begin{tabular}{cl}
\hline SKALA & \multicolumn{1}{c}{ INDIKATOR } \\
Kognisi & $\begin{array}{l}\text { Memahami kesalahan orang lain, meyakini } \\
\text { adanya kebaikan dalam pemaafan, tanggung } \\
\text { jawab terhadap kedamaian dan keselamatan } \\
\text { bersama. } \\
\text { Afeksi } \\
\text { Lapang dada, memperbaiki hubungan dengan } \\
\text { pelaku, mendoakan pelaku agar sadar dan } \\
\text { bertaubat, memintakan ampunan kepada } \\
\text { Allah kepada pelaku, bermusyawarah dan } \\
\text { membuka pintu dialog dengan pelaku, } \\
\text { Menjadi pemaaf, berserah diri kepada Allah, } \\
\text { menyerahkan semua urusan kepada Allah } \\
\text { (tawakkal) }\end{array}$ \\
\hline
\end{tabular}

\section{Faktor-Faktor yang Mempengaruhi Pemaafan}

Pemaafan dalam Islam dipengaruhi oleh satu faktor utama, yaitu faktor religiusitas (semakin tinggi religiusitas, semakin tinggi potensi pemaafan). Agama menjadi faktor yang sangat penting bagi seorang Muslim, karena ia menjadi pemandu dan petunjuk atas perjalanan hidupnya di dunia dan akhirat. Tanpa bimbingan agama, hidup seorang Muslim akan tersesat kepada jalan yang menyimpang dari ketentuan agama dan nilai-nilai kebaikan universal. Islam mengajarkan kepada umatnya prinsip dan nilai mulia/terpuji (akblaq mahmudab) dalam hidup yang harus diekspresikan dalam kehidupan sehari-hari. Jadi tidak hanya sekedar menjadi nilai dan prinsip yang diidealkan saja dan tidak membumi. Ide dasar dari pemikiran ini adalah bahwa seorang hamba harus mampu meniru sifat-sifat baik (asma' al-husna) yang dimiliki oleh Allah. Seseorang dianggap baik dalam beragama jika mampu berperilaku sesuai dengan dianjurkan agama (akblaq mahmudab), demikian juga sebaliknya. Oleh karena itu, seorang Muslim yang baik adalah orang yang mampu memaafkan setiap kesalahan orang lain, karena memaafkan

\footnotetext{
35 Ayat-ayat tersebut adalah: surat al-Baqarah: 219, 178; surat Ali Imran: 134, 159; surat al-Nur: 22; surat al-Syura: 40; surat al-Hijr: 85; surat al-Zukhruf: 89
} 
adalah salah satu sifat yang terpuji itu dan merupakan salah satu asma' albusna.

Seorang Muslim yang belajar ilmu agama dengan baik (menyeluruh dan mendalam), juga memiliki potensi menjadi pemaaf bagi orang lain. Perspektif teori pendidikan, tujuan pendidikan selain sebagai transfer of knowledge juga merupakan sarana untuk pembentukan karakter (character building). Secara teoritis proses pembelajaran secara sistematis bertujuan untuk mengkonstruksi perubahan pada diri seseorang. Artinya proses pembelajaran secara teoritis akan berpengaruh terhadap sikap seseorang. Hal ini sebagaimana pendapat Baharuddin, bahwa belajar adalah setiap perubahan tingkah laku yang relatif tetap dan terjadi sebagai hasil latihan atau pengalaman. ${ }^{36}$ Dalam konteks pendidikan Islam, hakikat pendidikan adalah dalam rangka menciptakan manusia sempurna secara intelektual, sosial, dan spiritual sesuai yang dimiliki oleh Nabi Muhammad sebagai contoh paripurna (al-mathal al-kāmil).

Perspektif ilmu psikologi, pemaafan pada seseorang dapat dipengaruhi oleh banyak faktor. Faktor-faktor tersebut adalah:

\section{Tingkat Penyesalan}

Tingkat penyesalan bisa jadi menjadi sebuah faktor kemauan seseorang untuk memaafkan dan oleh karenanya menjadi sebuah pertimbangan tambahan yang penting bagi peneliti. Pada dasarnya, sulit bagi seseorang untuk memaafkan orang lain ketika ia tidak mengakui bahwa ia telah melakukan kesalahan atau bertanggung jawab atas perbuatan salah mereka. ${ }^{37}$ Ketika berdiskusi dengan seorang klien yang menceraikan suaminya Haucks memahami bahwa seseorang yang sangat menyesal merasa sangat tidak bahagia dalam perbuatannya, merasa sakit, menderita, dan, dalam beberapa kasus, takut. Perasaan menyesal dapat menyebabkan dua hal: rasa bersalah dan belas kasih. Rasa bersalah muncul sebagai akibat menganggap diri sendiri tidak bijak, tidak baik,

\footnotetext{
36 Baharuddin \& Esa Nur Wahyuni, Teori Belajar Dan Pembelajaran, (Yogyakarta: Ar-Ruzz Media, 2009), hal. 14

${ }^{37}$ Bedell, The Role of Religiosity in Forgiveness, hal. 9
} 
tidak beretika, atau tidak beragama. ${ }^{38}$ Inilah yang menjadi faktor penyebab seseorang berpotensi memaafkan.

\section{Religiusitas (keberagamaan)}

Doktrin dan motivasi yang tinggi dalam agama diyakini menjadi faktor yang sangat berpengaruh terhadap kemauan seseorang untuk memaafkan orang lain. Salah satu alasan yang mendukung tentu adalah keinginan untuk mendapatkan ampunan dari Tuhannya dan semakin dekat dengan Tuhan. Sebuah penelitian menunjukan bahwa kegiatan kelompok agama yang bersifat emosional seperti sharing dan doa bersama, terbukti membantu individu memaafkan orang lain. ${ }^{39}$ Adanya pengaruh signifikan antara religiusitas dengan sikap pemaafan seseorang juga dapat diukur melalui intensitas hubungan seseorang dengan Tuhannya melalui kehadirannya ke tempat ibadah. Bedell menemukan bahwa intensitas kehadiran seseorang di tempat ibadah berpengaruh terhadap potensi pemaafannya. $^{40}$

Namun demikian tidak semua penelitian menggambarkan adanya pengaruh religiusitas terhadap pemaafan. Sebuah penelitian pilot study oleh Tsang, McCullough dan Hyot (2005) menyatakan bahwa secara tidak langsung religiusitas memiliki potensi untuk memunculkan pemaafan pada seseorang karena pada dasarnya setiap agama mengajarkan cinta dan kasih sayang yang mendorong sikap memaafkan. Akan tetapi, hasil dari penelitian ini menunjukkan bahwa kecil hubungan positif antara religiusitas dan pemaafan. Selain itu dalam penelitian yang sama, Tsang, McCullough dan Hyot (2005) menyatakan bahwa religiusitas juga dapat membuat seseorang melakukan pembalasan. Hal tersebut memungkinkan religiusitas sebagai alasan seseorang untuk tidak memaafkan kesalahan orang lain. Hasil penelitian tersebut tidak sejalan dengan hasil penelitian metanalisis tentang hubungan religiusitas dan pemaafan oleh Kurniati (2011) yang menyatakan bahwa ada hubungan

\footnotetext{
${ }^{38}$ Bedell, The Role of Religiosity in Forgiveness, hal. 9-10

39 Baca: A.F. Pertiwi, "Memaafkan Orang Lain: Kajian tentang Tindakan Memaafkan pada Subjek dengan Pengalaman Beberapa Kali Memaafkan Orang Lain”, Tesis, F.Psi. UI: Depok, 2004.

${ }^{40}$ Baca: Bedell, ., The Role of Religiosity in Forgiveness.
} 
positif antara religiusitas dengan pemaafan akan tetapi tidak ada hubungan signifikan antara religiusitas dengan unforgiveness. ${ }^{41}$

\section{Kualitas hubungan interpersonal}

Seseorang yang memaafkan kesalahan pihak lain dapat dilandasi oleh komitmen yang tinggi pada relasi mereka. Menurut McCullough, ada empat alasan mengapa kualitas hubungan berpengaruh terhadap perilaku memaafkan dalam hubungan interpersonal. Pertama, pasangan yang mau memaafkan pada dasarnya mempunyai motivasi yang tinggi untuk menjaga hubungan. Kedua, dalam hubungan yang erat ada orientasi jangka panjang dalam menlain hubungan di antara mereka. Ketiga, dalam kualitas hubungan yang tinggi kepentingan satu orang dan kepentingan pasangannya menyatu. Keempat, kualitas hubungan mempunyai orientasi kolektivitas yang menginginkan pihak-pihak yang terlibat untuk berperilaku yang memberikan keuntungan di antara mereka. ${ }^{42}$

\section{E. Kesimpulan}

Beberapa kesimpulan yang dapat disampaikan berdasarkan pemaparan dan analisis tema di atas adalah sebagai berikut:

1. Pemaafan adalah sebuah karakter dalam diri manusia yang secara kuat mengekspresikan kecenderungan untuk memahami kesalahan orang lain, menghindari balas dendam, selalu memelihara hubungan baik dengan sesama, dan menciptakan kedamaian dan keselamatan bagi semua.

2. Islam dan psikologi memiliki rumusan tentang aspek, dimensi, dan bentuk pemaafan yang memiliki banyak kemiripan. Perbedaan secara signifikan terletak pada muatan spiritual yang sangat kental dalam konsep Islam. Misalnya dalam hal aspek pemaafan, yaitu aspek penerimaan yang maksimal terhadap semua ketentuan Allah, sehingga agama menganjurkan untuk mendoakan orang yang berbuat kejahatan dan menyerahkan

\footnotetext{
${ }^{41}$ Tri Kurniati Amrilah, Prasetyo Budi Widodo, Religiusitas dan Pemaafan dalam Konflik Organisasi pada Aktivis Islam di Kampus Universitas Diponegoro, Jurnal Empati, Oktober 2015, volume 4(4), hal. 287-292

42 Latifah Tri Wardhati \& Faturochman, Psikologi Pemaafan, dalam http://fatur.staff.ugm.ac.id/file/ Psikologi\%20\%20Pemaafan.pdf, hal. 7. Diakses tanggal 27 Juli 2017 pukul 17.30
} 
semua urusan kepada-Nya (tawakkal). Contoh lain adalah adanya ketentuan khusus tentang pemaafan dalam fikih jinayah sebagai salah satu solusi hukum bagi kejahatan pembunuhan dan pelukaan.

3. Pemaafan dalam konsep Islam sangat dominan dipengaruhi oleh faktor keberagamaan (religiusitas). Hal ini karena, bagi seorang Muslim, agama adalah inspirasi utama dan sumber ajaran kebaikan yang harus diartikulasikan dalam kehidupan nyata demi kemaslahatan dan kerahmatan alam semesta.

\section{Referensi}

Alwi, Hasan, Kamus Besar Bahasa Indonesia, Jakarta: Gramedia Pustaka Utama, 2011.

Al-'Akkaz, Dr. Fikri Ahmad, Falsafat al-Uqubah fi al-Syari'ab wa al-Qanun, tp., 1982.

Amrilah, Tri Kurniati \& Prasetyo Budi Widodo, Religiusitas dan Pemaafan dalam Konflik Organisasi pada Aktivis Islam di Kampus Universitas Diponegoro, Jurnal Empati, Oktober, volume 4(4), 2015.

Audah, Abdul Qadir, al-Tasyri' al-Jina'i al-Islami, Beirut: Muassasah alRisalah, 1994.

Baharuddin \& Esa Nur Wahyuni, Teori Belajar dan Pembelajaran, Yogyakarta: Ar-Ruzz Media, 2009.

Bahtiar, Azam, "Al-'Afw dalam Pemikiran al-Syatibi dan Jamal al-Banna; Studi Komparatif”, dalam Jumal Sintesis, Volume 3 No. 1 Juni 2009.

Baskin, TW. \& Enright, R.D., "Intervention Studies on Forgiveness: A Meta-Analysis", dalam Journal of Counseling \& Development, Vol. 82 (Winter), 2004.

Bassiouni, M. Cherif, (ed.), The Islamic Criminal Justice System, New York: Oceana Publications, 1982.

Baumeister, R. F., J. J. Exline, and K. L. Sommer, The victim role, grudge theory, and two dimensions of forgiveness, dalam E. L. Worthington, Jr. (eds.), Dimensions of forgiveness: Psychological Research and Theological Speculations, Philadelphia: The Templeton Foundation Press, 1998.

Bedell, Tina Marie, B.A., M.A., The Role of Religiosity in Forgiveness, Dissertation, Ohio State University, 2002. 
Enright, R..D., Anthony Dio Martin, Emotional Quality Management: Refleksi, Revisi dan Revitalisasi Hidup Melalui Kekuatan Emosi, Jakarta: Penerbit Arga. 2003.

Hanafi, Ahmad D., Asas-Asas Hukum Pidana Islam, Jakarta: Bulan Bintang, 1993.

Ibn Faris bin Zakariya, Abul Husein Ahmad, Mu'jm al-Maqayis fi al-Lughah, tahqiq Syihabudin Abu Amar, Beirut: Dar al-Fikr, 1994.

Ibnu Qudamah, Al-Kafi fi figh Imam Ahmad Ibnu Hanbal, (tahqiq Jauhar Syawisy), Juz 4, Maktabah Islami, tt.

Khasan, Moh, "Prinsip-Prinsip Keadilan Hukum dalam Asas Legalitas Hukum Pidana Islam" dalam Jurnal Rechts Vinding, Vol. 6, Nomor 1, April 2017.

Al-Mawardi, al-Ahkam al-Sulthaniyah, Mesir: Babi al-Halabi, 1973.

McCullough, Fincham \& Tsang, Forgiveness, Forbearence, and Time: the Temporal Unfolding of Transgression-Related Interpersonal Motivations, Journal of Personality and Social Psychology, vol. 84, 2003.

McCullough, M.E., Jr. Worthington, \& K.C. Rachal, Interpersonal Forgiving in Close Relationships, Journal of Personality and Social Psychology, 1997.

Mona Gustafson-Affinito, When to Forgive: A Healing Guide, CA: New Harbinger Publication, 1999.

Mubarakfuri, Safi al-Ramadhan, Tafsir Ibn Katsir, Riyadh: Darussalam, 2003.

Muhammad, Ahsin Sakho, et.al (eds), Ensiklopedi Hukum Pidana Islam, Jakarta: PT. Kharisma Ilmu, 2007.

Al-Nasa'i, Abi Abdurrahman Ahmad ibn Syu'aib ibn 'Ali al-Khurasani, Sunan al-Nasa’', Beirut: Dar al-Kutub al-Ilmiyyah, 2002.

Nashori, Fuad, "Memaafkan dan Meminta Maaf", dalam bttp. :/ /alislamiyah.uii.ac.id/2013/02/06/memaafkan-dan-memintamaaf/

Nashori, Fuad, "Meningkatkan Kualitas Hidup dengan Pemaafan", dalam Jurnal Unisia, Vol. 32 No. 75, Juli 2011. 
Nashori, Fuad, M.Si, Psi., Psikologi Sosial Islami, Bandung: PT. Refika Aditama, 2008.

Nashori, Fuad, Pemaafan pada Etnis Jawa Ditinjau dari Faktor Demografi, dalam Jurnal Psikologika Vol 18 No. 2 Tahun 2013.

Pertiwi, A.F., "Memaafkan Orang Lain: Kajian tentang Tindakan Memaafkan pada Subjek dengan Pengalaman Beberapa Kali Memaafkan Orang Lain”, Tesis, F.Psi. UI: Depok, 2004.

Peterson, C., N. Park, M.E.P. Seligman, "Greater Strength of Character and Recovery from Illness", Journal of Positive Psychology, 2006.

Powell, Russell, "Forgiveness in Islamic Ethics and Jurisprudence", dalam Berkeley Jurnal of Middle Eastern and Islamic Law, Vol. 4:1, 2012.

Al-Qazwini, Abi Abdillah Muhammad ibn Yazid, Sunan Ibn Majah, Juz III, Beirut: Dar al-Ma'rifah, 2000.

Shihab, M. Quraish, Tafsir Tematik atas Pelbagai Persoalan Umat, Bandung: Mizan, 2007.

Skinner, S. Walrond, "The function and role of forgiveness in working with couples and families: Clearing the ground" dalam Journal of Family Therapy, 1998.

Sodiqin, Ali, Hukum Qiyas, Dari Tradisi Arab Menuju Hukum Islam, Yogyakarta: Tiara Wacana, 2010.

Al-Thabari, Abi Ja'far Muhammad bin Jarir, Jami' al-Bayan 'an Ta'wil alQur'an, Kairo: Maktabah ibn Taimiyyah, 1997.

Thompson, L.Y., Snyder, C.R., Hoffman, L., Michael, S.T., Rasmussen, H.N., Billings, L.S., Heinze, L., Neufeld, J.E., Shorey, H.S., Roberts, J.C., \& Robert, D.E., Dispositional Fogiveness of Self, Other, and Situation, Journal of Social and Personality Psychology, 73 (2)., 2005.

Tim, al-Mu'jam al-'Arab al-Asasi, Alesco L'Arousse: al-Munazhamah al'Arabiyah li al-Tarbiyah wa al-Tsaqafah wa al-'Ulum, 1989.

Wade, S.B., Gorsuch, R., \& Rosik, C.H., "The development of a scale tomeasure forgiveness", dalam Journal of Psychology and Christianity, 1990.

Wardhati Latifah Tri \& Faturochman, Psikologi Pemaafan, dalam http://fatur.staff.ugm.ac.id/file/ Psikologi\%20\%20Pemaafan.pdf, hal. 7. Diakses tanggal 27 Juli 2017 pukul 17.30. 